\title{
Questes
}

\section{La fresche mémoire : génération et régénération dans les Cent Nouvelles Nouvelles}

\section{Nelly Labere}

\section{(2) OpenEdition \\ 12 Journals}

Édition électronique

URL : http://journals.openedition.org/questes/2821

DOI : 10.4000/questes.2821

ISSN : 2109-9472

\section{Éditeur}

Les Amis de Questes

\section{Édition imprimée}

Date de publication : 15 décembre 2002

Pagination : 9-10

ISSN : 2102-7188

\section{Référence électronique}

Nelly Labere, "La fresche mémoire : génération et régénération dans les Cent Nouvelles Nouvelles »,

Questes [En ligne], 2 | 2002, mis en ligne le 01 janvier 2014, consulté le 15 septembre 2020. URL:

http://journals.openedition.org/questes/2821

Ce document a été généré automatiquement le 15 septembre 2020.

(c) Association des amis de «Questes » 


\section{La fresche mémoire : génération et} régénération dans les Cent Nouvelles Nouvelles

Nelly Labere

NOTE DE L'ÉDITEUR

Cet article n'a pas encore fait l'objet d'une autorisation de publication.

INDEX

Mots-clés : mémoire, narration, rupture, temps, innovation, génération

Keywords : memory, narration, break, time, innovation, generation 